\title{
The role of crop density, seed and aphid presence in diversification of field communities of Carabidae (Coleoptera)
}

\author{
ALOIS HONĚK ${ }^{1}$ and VoJTĚCH JAROŠÍI ${ }^{2}$ \\ Research Institute of Plant Production, Drnovská 507, 16106 Prague 6 - Ruzyně, Czech Republic; e-mail: honek@hb.vurv.cz \\ ${ }^{2}$ Faculty of Sciences, Charles University, Viničná 7, 12844 Prague 2, Czech Republic; e-mail: jarosik@mbox.cesnet.cz
}

Key words. Carabidae, abundance, activity, winter wheat, winter rape, metapopulation, microclimate

\begin{abstract}
In 1995-1997, we studied the factors which may influence the ground "activity density" of Carabidae using pitfall traps placed in winter wheat, winter rape and pea stands (1995 only) grown within a $1 \mathrm{~km}^{2}$ area with uniform physical conditions. The traps were placed in plots of bare ground established within the crops and under surrounding intact plant stands. The communities were similar between crops within years (Pearson's correlation coefficient $r=0.60-0.81)$, and between years within crops $(r=0.89$ - 0.91), except for the poor winter rape stand in 1997. Factors influencing carabid "activity density" were: (i) Density of crop stand. The carabids preferred crop-shaded ground as long as crop density was low or medium but moved to bare ground plots when crop density became high. Under moderate crop density the preference differed between beetle species, most of which preferred cropshaded ground while a few ones preferred bare ground. Carabid preferences were probably determined by microclimatic differences caused by presence and density of crop cover. (ii) Presence of seeds dropped on the ground. In rape stands, presence of crop and weed seeds increased the "activity density" of seed predators (species of genera Amara, Harpalus, Ophonus and Pseudoophonus). Scattering of rape seeds significantly increased local activity density of Harpalus affinis and $H$. distinguendus in the wheat stand. (iii) Presence of aphids. Activity density of Bembidion lampros and Trechus quadristriatus and between-year variation in pooled abundance of the five species recognised as aphid predators was associated with variation in aphid abundance.
\end{abstract}

\section{INTRODUCTION}

Numerous studies have investigated "activity density" of carabid species, i.e. number of individuals randomly moving per unit area over a unit time interval (Thiele, 1977). Activity density was usually estimated by pitfall traps whose catches are, for a given species, well correlated with absolute species abundance (Adis, 1979). Using pitfall traps is thus justified for comparing communities consisting largely of the same species. The studies revealed that carabid communities of arable land represent a set of species capable of withstanding agricultural practices (Luff, 1987), species which often disappear after the fields are abandoned (van Dijk, 1987). The abundant species are common over geographic areas with similar climates but their abundance varies annually. This variation concerns not only local populations (den Boer, 1977; Jones, 1979) but also metapopulations of larger areas (Honěk \& Pulpán, 1983). Therefore the relative importance of local factors for determining species abundance could only be revealed by a synchronous study.

The causes of local differences in carabid abundance include differing food availability and microclimate (Luff, 1987; Thiele, 1977). Aphids are eaten by several carabid species (Skuhravý, 1959; Lövei \& Sunderland, 1996) and sometimes may represent a substantial part of their food intake. Consequently, distribution of these species may be aggregated in parallel with the patchy distribution of aphids (Sunderland \& Vickermann, 1980; Scheller, 1984; Sopp \& Wratten, 1986; Chiverton, 1988; Winder et al., 1994). Other carabid species may be attracted by the presence of plant food, particularly seeds
(Kokta, 1988; Kromp, 1990; Jørgensen \& Toft, 1997). Microclimatic differences within and between stands are caused by variation in density and canopy structure of the crops. Crop density was demonstrated as a factor of carabid activity density, but the reports on its effects are contradictory. Some authors observed increased carabid activity density associated with "sparse" crop stands and the dry warm microclimate of the ground surface below their canopies, others with "dense" stands and cool and humid soil surface microclimates (Novák, 1967; Skuhravý et al., 1971; Petruška, 1971; Baker \& Dunning, 1975; Ericson, 1979; Varis et al., 1984; Wallin, 1985; Honěk, 1988, 1997).

In this study we compared carabid activity density in winter wheat, winter rape and pea stands grown simultaneously within a small $\left(1 \mathrm{~km}^{2}\right)$ experimental area for three years (1995-1997). This parallel design enabled us to establish factors that influence variation in abundance of species from the same metapopulation. The study was focused on effects of (i) crop stand density which varied within-crop microclimate, (ii) presence of seeds on ground surface and (iii) presence of aphid populations.

\section{MATERIAL AND METHODS}

\section{Crop stands}

The experiments were undertaken at Praha - Ruzyně $\left(50^{\circ} 06^{\prime}\right.$ $\mathrm{N} 14^{\circ} 16^{\prime} \mathrm{E}$, average May, June and July temperatures $12.7,16.3$ and $17.6^{\circ} \mathrm{C}$ and precipitation 57,64 and $70 \mathrm{~mm}$, respectively) on production fields situated within a $1 \mathrm{~km}^{2}$ experimental area located on a south facing slope ( $4 \%$ inclination), at 330-360 m a. s. 1. altitude. The experimental area is a mosaic of production and experimental fields divided by ridges and hedges, and with 
uniform soil quality. The crop rotation of the production fields was irregular, including different small grain cereals, oilseed rape, peas and alfalfa. In 1995-1997, carabids were collected in winter wheat and winter rape crops and also in a pea crop in 1995. The crops were grown using standard practices recommended in the Czech Republic (Špaldon, 1982). No insecticides were used from one month before and throughout the period of sampling

Three $4 \times 4 \mathrm{~m}$ plots cleared of crop and weed plants were established every year within each of the investigated stands. These plots were then kept free of weeds until the end of the experiment. The plots were arranged along a linear transect with $50 \mathrm{~m}$ spacing, at a minimum $50 \mathrm{~m}$ (pea, winter wheat) or $25 \mathrm{~m}$ (winter rape) distance from the field margin. Each year we recorded the development of above ground crop biomass in May and June. The crop biomass was used as an indicator of withinstand microclimate which could not be measured directly. The canopies of crops consisted of several leaf strata supported by erect (wheat, rape) or semi-prostrate (peas) stems. Due to the similarity in canopy structure we consider that the same crop density (aboveground biomass per unit area) created similar microclimates. Crop shoots were harvested near to the experimental plots from three $0.25 \mathrm{~m}^{2}$ plots, immediately weighed and recalculated to crop biomass. $\mathrm{m}^{-2}$. Crop samples were taken at weekly intervals and the values for between sampling days estimated by interpolation

\section{Trapping procedure}

The carabids were collected by pitfall traps, plastic cups of 7 $\mathrm{cm}$ diameter $\left(38.5 \mathrm{~cm}^{2}\right.$ outlet area), $8 \mathrm{~cm}$ deep. The cups were dug into the soil, with the rim at the soil surface, and screened from rain and sunshine by a dish wrapped in aluminium foil. No bait was used. A few pieces of soil at the bottom of the cups provided shelter for the trapped arthropods. At each experimental plot, three $(1995)$ or four $(1996,1997)$ pitfall traps were dug on bare ground, and the same number of pitfall traps were dug within the crop stand surrounding the bare ground plots, ca. $1.2 \mathrm{~m}$ from its edge (this enabled trap servicing with minimum disturbance of the crop stand). The traps were run from May 10 (winter wheat, winter rape) or May 26 (pea) until July 24, 1995, May 29 - Aug. 1, 1996, and May 30 - July 30, 1997. The traps were emptied at two day or three day (weekends) intervals, between 09:00-12:00 h. Individuals that were identified to species were counted and immediately released, some species were preserved for further determination. Samples of species of the genus Amara Bonelli were collected at weekly intervals, the beetles were killed and determined by Professor Karel Hůrka from Charles University, Prague.

\section{Seed presence}

Species of carabid tribus Zabrini (genus Amara) and Harpalini (Harpalus Latreille, Ophomus Dejean, Pseudoophomus Motschulsky) were regarded as granivorous (Zhavoronkova, 1969; Brandmayr, 1990). The effect of seed presence on their density was inferred from association between presence of seeds on ground surface and their abundance. Availability of seeds on the ground surface was established by visual recording of (i) spontaneously liberated winter rape seeds from maturing pods and (ii) presence of weeds with early seed dispersal, Lamium amplexicaule, Stellaria media and Veronica persica.

The effect of seed presence on carabid activity density was also investigated by the experiment established in a sparse winter wheat stand with minimum weed presence. Between June 21 - July 15, 1996 we compared the catches of (i) traps surrounded by artificially scattered oilseed rape seeds, (ii) traps where rape seeds were outside (as in i) and inside the trap and (iii) traps with no seeds outside or inside the trap (controls). The seeds around the traps were scattered at density of ca. 150 seeds per $0.01 \mathrm{~m}^{2}$, about $25 \mathrm{~cm}$ around its edge, and replaced (with 0.5 cm upper soil layer) at four day intervals to prevent seed germination. The design of the pitfall traps, frequency of servicing and recording of carabid catches were as described above. The traps (i), (ii) and (iii) were placed alternately in 2 replicates, along a line transect with $8 \mathrm{~m}$ spacing.

\section{Aphid populations}

In 1995-1997, there were virtually no aphids in winter rape stands. In winter wheat aphid populations consisted mainly of Sitobion avenae (F.) and Metopolophium dirhodum (Walker). Their counts were taken weekly, using standard methods described in detail by Honěk (1991) and Honěk \& Martinková (1999). The effect of aphid presence on carabid activity was inferred from a relationship between maximum aphid abundances (pooled count of all species) and the activity density of carabid species recognised as aphid predators (Sopp \& Wratten, 1986; Chiverton, 1988; Winder et al., 1994; Bilde \& Toft, 1997) during the period from 1 week before to 1 week after the time of the aphid maximum.

\section{Statistical procedures}

Annual and between-crop variation. The similarity between two samples of carabid communities was measured by Pearson's correlation coefficient $r$. The correlation coefficients were calculated for wheat samples and rape samples between years, for wheat vs. rape samples within each year, and for bare ground vs. within crop plots in wheat and rape. The similarities were assessed based on pooled annual catches of individual species in all traps, using a square root +0.5 transformation of the counts (Sokal \& Rohlf, 1981). Differences between the activity density of individual species between crops were tested by one-way ANOVAs with winter wheat and winter rape as a factor. Differences between activity density on bare ground and under crop cover were analysed within each crop using each plot with bare ground and within crop traps as statistical blocks, and bare ground and crop cover as factors. Pooled annual catches, giving six replicates in each analysis, were used as the response variables. For between crop comparisons replicates were obtained from pooled catches of all traps (bare ground + within crop) in three plots in wheat and rape, and in comparisons between bare ground and crop cover from three pooled catches in bare ground and within crop traps. The analyses were made separately for each year and species, using a square root +0.5 transformation of the counts. The adequacy of the fitted statistics were checked by plotting standardised residuals against fitted values, and by the normal probability plots of the fitted values (Crawley, 1993). In all cases, the transformation appeared adequate.

Spatial patterns. The same data were used to investigate spatial pattern of distribution of the species. The randomness of distribution was tested by comparing the goodness of fit of index of dispersion to random spatial pattering. This was checked by $\chi^{2}$-test (Krebs, 1989, p. 72-78). To find a more robust pattern of species distribution, the replicates of all species over the three year period were analysed by the estimate of parameter $k$ of the negative binomial distribution. It was performed by the maximum likelihood method following Krebs, 1989 (p. 81-93). Low values of $k$ indicate high degrees of aggregation. The goodness of fit of the estimated parameter $k$ to negative binomial distribution was checked by a G-test (Crawley, 1993, p. 339).

Crop density. The effect of crop density on carabid preferences for crop shaded or bare ground was tested by ANCOVA. Logit proportions of captures on bare ground at particular days 
when crop densities varied (May 10 - June 30, 1995) were used as the response variable. The logit was expressed as $\ln (p / 1-p)$, where $p$ was proportion of capture on bare ground. Wheat, pea, and rape crops were used as factors, and crop densities as a covariate. The analysis was weighted for sample sizes (total bare ground + within crop captures), assuming that the errors in the response variable followed a binomial distribution (Cox, 1970). McCullagh \& Nelder's (1989) treatment of overdispersion was followed, that is the data were rescaled using a dispersion factor which was calculated by dividing Pearson's $\chi^{2}$ by the residual degrees of freedom. The calculation was made using general linear modelling in GLIM $^{\mathbb{B}}$ v. 4 (Francis et al., 1994). The aim was to determine the minimal adequate model, i.e. a model in which all parameters were significantly $(p<0.05)$ different from zero and from one another. This was achieved by a step-wise process of model simplification, beginning with the full model (containing the factor, the covariate and all interactions that might be of interest), then proceeding by the elimination of non-significant terms (using deletion tests), and the retention of significant terms (Crawley, 1993). The modelling started by fitting the maximal model where each crop was regressed on its density with different intercepts and different slopes. The parameters of the maximal model were inspected, and the least significant term removed in a deletion test. If the deletion caused an insignificant increase in deviance, the term was left out of the model. The inspection of parameter estimates was repeated, and the least significant term remaining in the model removed. If the deletion caused a significant increase in deviance, the term was returned. The deletion tests were repeated until the minimal adequate model that contained nothing but significant terms was determined.

Seed predation. The effect of artificial scattering of oilseed rape seeds in winter wheat on carabid activity density was tested by one-way ANOVAs using the dominant granivorous and carnivorous species during the experiment. Square root +0.5 transformation of the total counts of each dominant species in each trap was the response variable, and traps with seeds outside, outside and inside, and no seeds were the factors.

\section{RESULTS}

Annual and between-crop variation. Fifty eight carabid species (Appendix) were captured during the study period. Nine abundant species (Table 1 and 2) had average catches during the June - July period greater than 0.1 individuals trap ${ }^{-1} \mathrm{day}^{-1}$, in bare ground or within crop traps, in at least one crop and year. This means a total catch greater than 55 (1995) or 73 (1996 and 1997) individuals over the June - July period. Three Amara species, i.e. A. littorea, $A$. ovata and $A$. similata also exceeded this abundance in at least one year in winter rape stand, and the total number of abundant species was thus 12 . We refer to Amara spp. as a complex since not all species were identified every day. Using pooled Amara spp. catches did not influence the significance of statistical calculations. The numbers of abundant species as well as total carabid abundance varied between years. The pooled catches increased in winter wheat $(0.85,2.20$ and 3.01 individuals trap ${ }^{-1}$ day $^{1}$ in 1995, 1996 and 1997, respectively) but decreased in winter rape $(4.43,4.11$ and 3.98 individuals trap ${ }^{-1}$ day $^{-1}$ ).

Variation in abundance of dominant species was also diachronic and the composition of carabid communities gradually changed during the three year period. The overall similarity between pairs of two successive years as measured by Pearson's correlation coefficient $r$ was very high in cases when crop density was near to that recommended for agriculture production $(r=0.90$ in 1995 vs. 1996 samples and $r=0.91$ in 1996 vs. 1997 samples in winter wheat, and $r=0.89$ in 1995 vs. 1996 in winter rape). In 1997 the winter rape stand was poor and its carabid community was marked by high abundance of Brachinus explodens and scarcity of Pseudoophonus rufipes (see below). Therefore the similarity between the 1996 and 1997 samples from winter rape was lower $(r=$ 0.74). The overall similarity between samples from successive years decreased as the time lag between compared years increased. The correlation between 1995 vs. 1997 was $r=0.84$ in winter rape, and $r=0.69$ in winter wheat (Table 3).

Due to the variation of carabid communities between years, crop effects were evaluated each year separately. The similarity of winter wheat and winter rape communities was highest in $1995(\mathrm{r}=0.81, \mathrm{p}=1.93 \mathrm{E}-09)$, smaller in $1996(\mathrm{r}=0.60, \mathrm{p}=0.00021)$ and lowest in $1997(\mathrm{r}=$ $0.56, p=0.0018$ ) (Table 3 ). The variation in similarity was associated with variation of crop density. The average above ground wet biomass between June $10-30$ (at the time of maximum shading of the ground surface) was similar in winter wheat, $4.5,3.8$ and $4.1 \mathrm{~kg} \mathrm{~m}^{-2}$ in 1995, 1996 and 1997, respectively. By contrast, the density of winter rape stands varied between years $(6.8,4.0$, and $2.3 \mathrm{~kg} \mathrm{~m}^{-2}$ ). In 1997 the rape stand was poor due to heavy damage by Ceutorrhynchus Germar spp. In 1995 and 1996, similarity between wheat and winter rape samples was greater for bare ground traps $(r=0.83$ and 0.81$)$ than within crop traps $(r=0.71$ and 0.60$)$ where it was apparently influenced by differences in crop quality. In 1997, the similarity was low in both bare ground ( $\mathbf{r}=$ $0.59)$ and within crop $(r=0.57)$ samples (Table 4$)$.

Although the relative abundances of individual species compared by Pearson's correlation coefficients were similar each year in both stands (Fig. 1), the total species abundances (Table 1 and 2) tested by ANOVA were higher in winter rape than winter wheat (1995: $\mathrm{F}=$ $481.14 ; \mathrm{df}=1,7 ; \mathrm{p}=3.36 \mathrm{E}-06 ; 1996: \mathrm{F}=85.06 ; \mathrm{df}=1,7$; $p=3.64 \mathrm{E}-05 ; 1997: \mathrm{F}=60.14 ; \mathrm{df}=1,7 ; \mathrm{p}=0.00011)$. Consequently, activity densities of several species were significantly $(\mathrm{p}<0.05)$ higher in winter rape than winter wheat (Fig. 1): Acupalpus meridianus, Amara spp., Anchomenus dorsalis, B. explodens, Harpalus affinis, $H$. distinguendus, H. tardus, Microlestes minutulus, Notiophilus aquaticus, Ophonus azureus, Poecilus cupreus, and Pseudoophonus griseus. Conversely, Bembidion lampros, Carabus granulatus and Trechus quadristriatus were the only species significantly more abundant in winter wheat than winter rape. Relative abundances of $P$. rufipes and Stomis pumicatus varied significantly with year and crop (see section Crop density).

Spatial patterns. The spatial patterns of individual species distribution within the investigated crop stands did not follow a consistent pattern. The pattern varied widely from random to strongly aggregated distribution, with no 
TABLE 1. Average catches (individuals.trap ${ }^{-1}$.day ${ }^{-1}$ ) over June-July period in winter wheat, in traps placed on bare ground plots (BGD), under crop cover (CRP), and the pooled average (TOT). Included are species with catch $\geq 0.01$ in at least one year on either bare ground or under crop cover. 0.00 means an average catch of $0.001-0.004$ individuals.trap ${ }^{-1}$.day ${ }^{-1}$, -- means zero catch. Bold figures indicate significant differences $(\mathrm{p}<0.05)$ between bare ground and crop cover samples tested by ANOVA.

\begin{tabular}{|c|c|c|c|c|c|c|c|c|c|}
\hline \multirow{2}{*}{ Species } & \multicolumn{3}{|c|}{1995} & \multicolumn{3}{|c|}{1996} & \multicolumn{3}{|c|}{1997} \\
\hline & BGD & CRP & TOT & BGD & CRP & TOT & BGD & CRP & TOT \\
\hline Amara spp. & 0.05 & 0.02 & 0.03 & 0.04 & 0.02 & 0.03 & 0.01 & 0.01 & 0.01 \\
\hline Anchomenus dorsalis & 0.07 & 0.13 & 0.10 & 0.11 & 0.28 & 0.19 & 0.02 & 0.30 & 0.16 \\
\hline Bembidion lampros & 0.24 & 0.04 & 0.14 & 0.18 & 0.23 & 0.20 & 0.17 & 0.12 & 0.14 \\
\hline Bembidion obtusum & 0.00 & 0.02 & 0.01 & 0.02 & 0.04 & 0.03 & 0.01 & 0.03 & 0.02 \\
\hline Bembidion quadrimaculatum & 0.01 & -- & 0.00 & 0.00 & -- & 0.00 & 0.00 & -- & 0.00 \\
\hline Brachinus explodens & -- & -- & -- & 0.00 & 0.00 & 0.00 & 0.00 & 0.01 & 0.00 \\
\hline Calathus ambiguus & -- & -- & -- & -- & -- & -- & 0.00 & 0.01 & 0.01 \\
\hline Calathus fuscipes & -- & -- & -- & 0.04 & 0.01 & 0.03 & 0.03 & 0.06 & 0.05 \\
\hline Calathus melanocephalus & -- & -- & -- & -- & 0.01 & 0.00 & -- & 0.00 & 0.00 \\
\hline Carabus cancellatus & -- & -- & -- & 0.02 & 0.03 & 0.03 & 0.00 & 0.02 & 0.01 \\
\hline Carabus gramulatus & -- & -- & -- & 0.00 & 0.02 & 0.01 & 0.01 & 0.05 & 0.03 \\
\hline Harpalus affinis & 0.26 & 0.02 & 0.14 & 0.42 & 0.08 & 0.25 & 0.08 & 0.06 & 0.07 \\
\hline Harpalus distinguendus & 0.07 & 0.01 & 0.04 & 0.04 & 0.01 & 0.03 & 0.01 & 0.00 & 0.00 \\
\hline Harpalus signaticornis & -- & -- & -- & -- & 0.00 & 0.00 & 0.00 & 0.01 & 0.00 \\
\hline Harpalus tardus & 0.01 & 0.00 & 0.01 & 0.01 & 0.00 & 0.01 & 0.00 & 0.00 & 0.00 \\
\hline Loricera pilicornis & 0.00 & 0.02 & 0.01 & 0.00 & 0.01 & 0.01 & 0.00 & 0.01 & 0.01 \\
\hline Microlestes minutulus & 0.01 & -- & 0.00 & 0.05 & - & 0.02 & 0.02 & -- & 0.01 \\
\hline Notiophilus aquaticus & 0.01 & -- & 0.00 & 0.01 & 0.00 & 0.01 & 0.00 & -- & 0.00 \\
\hline Ophonus azureus & 0.00 & -- & 0.00 & 0.00 & 0.00 & 0.00 & 0.01 & 0.01 & 0.01 \\
\hline Poecilus cupreus & 0.23 & 0.05 & 0.14 & 0.28 & 0.38 & 0.33 & 0.19 & 0.23 & 0.21 \\
\hline Pseudoophonus griseus & -- & -- & -- & 0.01 & 0.01 & 0.01 & 0.01 & 0.02 & 0.02 \\
\hline Pseudoophomus rufipes & 0.22 & 0.08 & 0.15 & 0.32 & 0.39 & 0.35 & 0.55 & 1.05 & 0.80 \\
\hline Pterostichus melanarius & 0.06 & 0.27 & 0.04 & 0.29 & 0.61 & 0.45 & 0.79 & 1.39 & 1.09 \\
\hline Stomis pumicatus & -- & 0.00 & 0.00 & 0.02 & 0.01 & 0.01 & 0.02 & 0.03 & 0.02 \\
\hline Trechus quadristriatus & 0.00 & 0.05 & 0.03 & 0.11 & 0.28 & 0.19 & 0.12 & 0.53 & 0.32 \\
\hline Total & 1.24 & 0.47 & 0.85 & 1.96 & 2.44 & 2.20 & 2.07 & 3.95 & 3.01 \\
\hline
\end{tabular}

TABLE 2. Average catches (individuals.trap ${ }^{-1}$ day ${ }^{-1}$ ) over June-July period in winter rape, in traps placed on bare ground plots (BGD), under crop cover (CRP), and the pooled average (TOT). Otherwise as in Tab. 1.

\begin{tabular}{|c|c|c|c|c|c|c|c|c|c|}
\hline \multirow{2}{*}{ Species } & \multicolumn{3}{|c|}{1995} & \multicolumn{3}{|c|}{1996} & \multicolumn{3}{|c|}{1997} \\
\hline & BGD & CRP & TOT & BGD & CRP & TOT & BGD & CRP & TOT \\
\hline Acupalpus meridianus & 0.04 & 0.01 & 0.02 & 0.02 & 0.01 & 0.01 & 0.01 & 0.01 & 0.01 \\
\hline Amara spp. & 0.29 & 0.77 & 0.53 & 0.49 & 1.82 & 1.16 & 0.19 & 0.43 & 0.31 \\
\hline Anchomenus dorsalis & 0.70 & 0.34 & 0.52 & 0.20 & 0.51 & 0.35 & 0.12 & 0.51 & 0.31 \\
\hline Bembidion lampros & 0.22 & 0.03 & 0.12 & 0.05 & 0.03 & 0.04 & 0.22 & 0.11 & 0.16 \\
\hline Bembidion obtusum & 0.02 & 0.05 & 0.03 & 0.02 & 0.01 & 0.02 & 0.00 & 0.01 & 0.01 \\
\hline Bembidion quadrimaculatum & 0.01 & 0.00 & 0.01 & 0.00 & 0.00 & 0.00 & -- & 0.00 & 0.00 \\
\hline Brachinus explodens & 0.01 & 0.02 & 0.02 & 0.04 & 0.06 & 0.05 & 0.12 & 0.66 & 0.39 \\
\hline Calathus fuscipes & -- & -- & -- & 0.02 & 0.01 & 0.01 & -- & 0.01 & 0.01 \\
\hline Carabus cancellatus & -- & -- & -- & 0.01 & 0.01 & 0.01 & 0.01 & 0.02 & 0.02 \\
\hline Carabus gramulatus & -- & -- & -- & 0.01 & 0.01 & 0.01 & -- & 0.00 & 0.00 \\
\hline Harpalus affinis & 0.53 & 0.47 & 0.50 & 0.39 & 0.51 & 0.45 & 0.14 & 0.50 & 0.32 \\
\hline Harpalus distinguendus & 0.93 & 0.60 & 0.77 & 0.21 & 0.17 & 0.19 & 0.07 & 0.21 & 0.14 \\
\hline Harpalus signaticornis & 0.12 & 0.04 & 0.08 & 0.01 & 0.01 & 0.01 & -- & 0.00 & 0.00 \\
\hline Harpalus tardus & 0.01 & 0.01 & 0.01 & 0.02 & 0.06 & 0.04 & 0.00 & 0.00 & 0.00 \\
\hline Loricera pilicornis & 0.00 & 0.02 & 0.01 & 0.01 & 0.02 & 0.01 & 0.01 & 0.02 & 0.01 \\
\hline Microlestes minutulus & 0.08 & - & 0.04 & 0.02 & -- & 0.01 & 0.04 & 0.00 & 0.02 \\
\hline Notiophilus aquaticus & 0.06 & 0.00 & 0.03 & 0.00 & 0.01 & 0.01 & -- & 0.01 & 0.01 \\
\hline Ophonus azureus & 0.02 & 0.01 & 0.01 & 0.00 & 0.01 & 0.01 & 0.01 & 0.01 & 0.01 \\
\hline Poecilus cupreus & 1.75 & 0.51 & 1.13 & 0.48 & 0.52 & 0.50 & 1.37 & 1.74 & 1.56 \\
\hline Pseudoophonus griseus & 0.00 & 0.01 & 0.01 & 0.01 & 0.02 & 0.02 & -- & -- & -- \\
\hline Pseudoophonus rufipes & 0.76 & 0.71 & 0.75 & 0.90 & 1.01 & 0.95 & 0.07 & 0.15 & 0.11 \\
\hline Pterostichus melanarius & 0.14 & $\mathbf{0 . 3 0}$ & 0.22 & 0.16 & 0.27 & 0.21 & 0.24 & 0.68 & 0.46 \\
\hline Stomis pumicatus & -- & 0.00 & 0.00 & 0.03 & 0.05 & 0.04 & 0.00 & 0.01 & 0.01 \\
\hline Trechus quadristriatus & 0.00 & 0.13 & 0.06 & 0.01 & 0.01 & 0.01 & 0.03 & 0.21 & 0.12 \\
\hline Total & 5.69 & 4.03 & 4.43 & 3.11 & 5.13 & 4.11 & 2.65 & 5.30 & 3.98 \\
\hline
\end{tabular}


TABLE 3. Between year similarity of samples of the communities of carabid beetles in winter wheat (below left) and winter rape (above right). Pearson's correlation coefficients are used as similarity indices between square root +0.5 species abundances.

\begin{tabular}{lccc}
\hline & 1995 & 1996 & 1997 \\
\hline 1995 & -- & 0.89 & 0.84 \\
1996 & 0.90 & -- & 0.74 \\
1997 & 0.69 & 0.91 & -- \\
\hline
\end{tabular}

consistent trend in relation to crop, bare ground, crop cover, or abundance of individual species.

Crop density. Variation of crop density and the associated microclimatic differences significantly affected activity density of several species. Comparing catches from bare ground and within crop traps (Table 1 and 2) revealed that some species preferred dwelling under crop canopy, others on bare ground plots. The catches of 9 species, A. dorsalis, Bembidion obtusum, B. explodens, Carabus cancellatus, Carabus granulatus, H. tardus, Loricera pilicornis, Pterostichus melanarius and T. quadristriatus, were greater in within crop than bare ground traps in all cases (crop $\times$ year combinations) when the difference was significant. By contrast, 5 species, $A$. meridianus, B. lampros, B. quadrimaculatum, M. minutulus, and $N$. aquaticus were always more abundant on the bare ground than within crops. The preferences of several other species (Amara spp., Calathus fuscipes, H. affinis, and often also $H$. distinguendus and $P$. rufipes) varied with crop. In winter wheat stands these species were more abundant under srop cover than on bare ground while in winter rape stands they were more abundant on bare ground than under crop canopy. P. cupreus, one of the top abundant species of the carabid community, had no consistent trend of abundance.

TABLE 4. Similarity of samples from winter wheat and winter rape crops collected on bare ground (BGD) and within crop (CRP) traps. Pearson's correlation coefficients are used as similarity indices between square root +0.5 species abundances of the carabid beetle communities.

\begin{tabular}{lll}
\hline & BGD & CRP \\
\hline 1995 & 0.83 & 0.71 \\
1996 & 0.81 & 0.60 \\
1997 & 0.59 & 0.57 \\
\hline
\end{tabular}

The densities of some species varied with changes in crop stand density. In 1995, a change in activity density could be shown for $P$. rufipes and $H$. distinguendus in the rape stand (Fig. 2). The stand was dense and ground surface was completely shaded until early July. As the crop matured and the foliage became sparse sunshine began to penetrate crop cover and reach the soil surface. In parallel with these changes the activity density of both species was greater on bare ground plots until late June, thereafter it gradually increased under crop cover. The annual mean density of both species was higher on bare ground than under dense crop cover. Conversely, in 1997 when the rape stand was sparse, the density of $P$. rufipes and $H$. distinguendus was significantly higher under crop cover (Table 2).
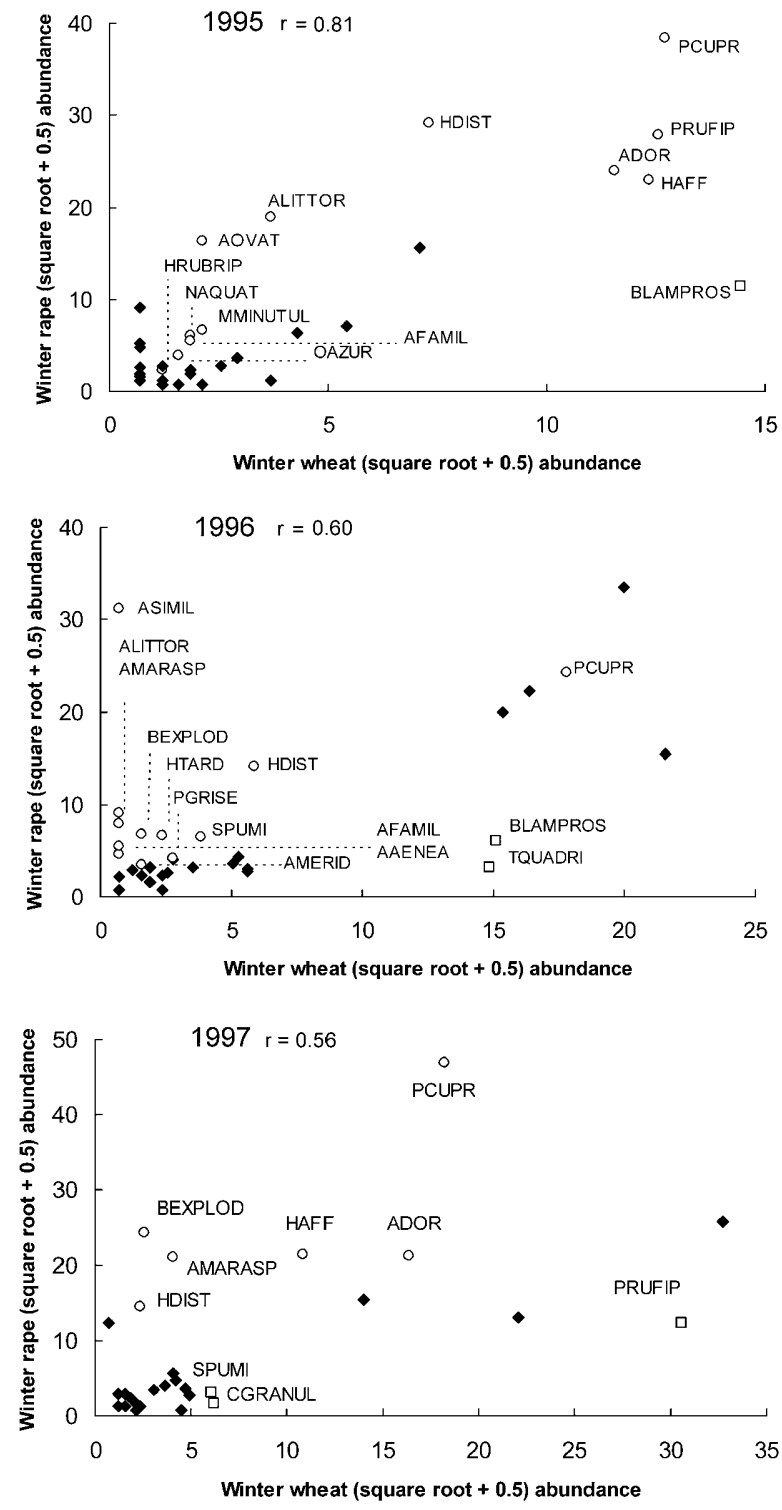

Fig. 1. Pearson's correlation coefficients $r$ of similarity between square root +0.5 abundances of individual species of carabid beetle communities in winter rape and winter wheat in 1995-1997. Labelled species are significantly $(p<0.05)$ more abundant in rape (open circles) or wheat (open squares) in ANOVA tests. Heavy diamonds (not labelled) represent species whose activity density did not significantly differ between wheat and rape stands. AMERID - A. meridianus, AAENEA A. aenea, ADOR - A. dorsalis, AFAMIL - A. familiaris, ALITTOR - A. littorea, AOVAT - A. ovata, ASIMIL - A. similata, AMARASP - Amara spp., BLAMPROS - B. lampros, BEXPLOD - B. explodens, CGRANUL - C. granulatus, HAFF - H. affinis, HDIST - H. distinguendus, HRUBRIP - H. rubripes, HTARD - H. tardus, MMINUTUL - M. minutulus, NAQUAT $-N$. aquaticus, OAZUR $-O$. azureus, PCUPR $-P$. cupreus, PGRISE -P. griseus, PRUFIP - P. rufipes, SPUMI S. pumicatus, TQUADRI - T. quadristriatus.

Due to changes in the density of the dominant species, the activity density of the total carabid density from within crop and bare ground plots often varied as crop density and within-crop microclimate changed. In May 
TABLE 5. Numbers of aphids (individuals/tiller at the time of aphid population peak) and numbers of the principal aphid predators (individuals.trap ${ }^{-1}$. day ${ }^{-1}$ calculated from mean numbers over \pm 3 days around the aphid peak) in winter wheat stands. PCUPR $-P$. cupreus, PMELAN - P. melanarius, ADOR - A. dorsalis, BLAMPROS - B. lampros, TQUADRI - T. quadristriatus.

\begin{tabular}{lccccccc}
\hline \multirow{2}{*}{ Date of peak } & $\begin{array}{c}\text { Aphid abundance } \\
\text { (ind tiller }{ }^{-1} \text { ) }\end{array}$ & \multicolumn{5}{c}{ Carabid abundance (ind trap ${ }^{-1}$ day $^{-1}$ ) } \\
\cline { 3 - 8 } & & PCUPR & PMELAN & ADOR & BLAMPROS & TQUADRI & TOTAL \\
\cline { 3 - 8 } & & 0.13 & 0.03 & 0.10 & 0.09 & 0.02 & $\mathbf{0 . 3 7}$ \\
June 20, 1995 & $\mathbf{0 . 2 4}$ & 0.08 & 0.87 & 0.04 & 0.09 & 0.02 & $\mathbf{1 . 0 9}$ \\
July 22, 1996 & $\mathbf{4 . 9 6}$ & 0.39 & 0.81 & 0.14 & 0.17 & 0.31 & $\mathbf{1 . 8 2}$ \\
\hline
\end{tabular}

and June, before the onset of crop senescence, microclimate was correlated with crop density. The effect of crop density on carabid preferences could be demonstrated between May 10 - June 30, 1995 when crop densities varied between $0.52-8.1 \mathrm{~kg} . \mathrm{m}^{-2}$. In rape and pea, the proportion of beetles caught in bare ground traps significantly increased with the density of surrounding crop (regression slope $=0.24 \pm 0.03 ; \mathrm{F}=68.87 ; \mathrm{df}=1,42 ; \mathrm{p}=$ $2.15 \mathrm{E}-10)$, and the increase did not differ between these crops $\left(\mathrm{F}_{\text {residuals for different regression slope }}=0.073\right.$; $\mathrm{df}=1,41 ; \mathrm{p}=$ 0.79 ). This means that carabids preferred to shelter within plant stands when crop density was low but became aggregated on bare ground plots when surrounding crops became dense. This trend however appeared insignificant in wheat $\left(\mathrm{F}_{\text {residuals for regression slope }}=0.157 ; \mathrm{df}=1,39 ; \mathrm{p}=0.69\right)$ (Fig. 3).

Seed presence. Winter wheat and rape crops differed in the numbers of seeds available on the ground. In winter wheat, dicotyledoneous weeds, the only source of seeds, were scarce due to spring herbicide treatments. By contrast, in winter rape dicotyledoneous weed species were abundant and crop seeds were also released from the 1 st decade of July. Seed predators (species of genera Amara, Harpalus, Ophonus, and Pseudoophonus) were significantly more abundant in winter rape than winter wheat stands (except for $P$. rufipes in 1997) (Fig. 1). In addition, Amara spp., H. affinis, and often also $H$. distinguendus and $P$. rufipes, were more abundant in wheat on bare ground, but in rape under crop cover (Table 1 and 2). Seeds released from crop and weed plants and scattered

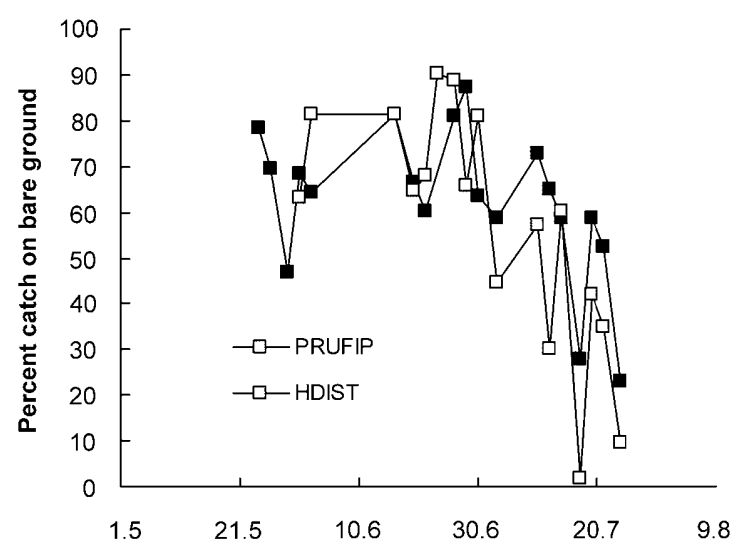

Fig. 2. The variation in the percentage of catch of $P$. rufipes (PRUFIP) and $H$. distinguendus (HDIST) on bare ground in the winter rape stand in May-Aug. 1995. Only the data calculated from catches of more than 10 beetles are shown. on ground surface could promote activity densities of these species under winter rape crop cover.

The attractiveness of rape seeds was tested in the winter wheat stand. Activity density around traps surrounded by scattered oilseed rape seeds and traps with no seeds around was compared amongst the three most abundant granivorous species (H. affinis, $H$. distinguendus, $P$. rufipes) and three most abundant carnivorous species ( $P$. melanarius, $P$. cupreus, $A$. dorsalis). The presence of seeds around and inside the trap significantly increased activity density of two granivourous species, $H$. affinis and $H$. distinguendus (Fig. 4) but not the activity of the third granivorous species, $P$. rufipes whose density was lower where seeds were also inside the trap. The catches of carnivorous species were not significantly affected (except for P. cupreus) (Fig. 4).

Aphids. In 1995-1997, aphids were present only on winter wheat while winter rape stands were virtually free of aphids. In winter wheat, pooled abundance of aphid predators $P$. cupreus, $P$. melanarius, A. dorsalis, B. lampros and $T$. quadristriatus was greater in years of increased aphid abundance (Table 5). This was, however, not true for individual species. Differences in activity density between crops were also only loosely correlated with aphid presence in winter wheat. P. cupreus and

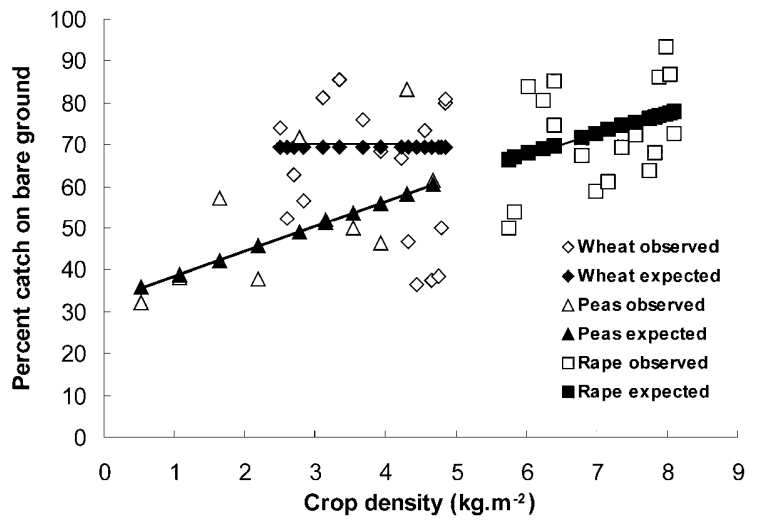

Fig. 3. Proportion of total carabid sample captured in traps placed at bare ground plots in relation to crop density. The points represent captures and actual crop densities on particular days between May 10 - June 30, 1995. Crop density indicated as $\mathrm{kg}$ wet above ground biomass. $\mathrm{m}^{-2}$. Expected values of captures are calculated from the minimal adequate model of ANCOVA in which $p$ is proportion of the catch on bare ground. Wheat: $\ln (p / 1-p)=0.82$; peas and rape: $\ln (p / 1-p)=-0.71+0.24$ crop density $\left(\mathrm{F}=35.35 ;\right.$ df 2,$\left.41 ; \mathrm{p}=1.19 \mathrm{E}-09 ; \mathrm{r}^{2}=63.3 \%\right)$. 
A. dorsalis were significantly more abundant in rape than wheat (Fig. 1), abundance of P. melanarius did not differ between crops. Only the abundance of $B$. lampros and T. quadristriatus was significantly greater in wheat (Fig. 1) and might be influenced by the distribution of aphids which are an important prey of both species.

\section{DISCUSSION}

\section{Similarity of communities}

The study established differences in carabid activity density that arose in winter wheat and winter rape crops grown in three successive years in a small area with uniform physical conditions. Carabid communities appeared very similar (Fig. 1, Table 3-4), with differences between communities of both crops originating through modification of the common set of species typical for the area. Other studies of small grain cereals and oilseed rape undertaken at various places in the Czech Republic (Novák, 1967; Petruška, 1971; Jarošík \& Hůrka, 1986) reported on communities with different species compositions. The differences were apparently due to temporal and spatial variation in the carabid metapopulations. The results thus justify the original assumption for the need of a parallel study to reveal the causes of between crop variation in carabid communities.

\section{Crop density and microclimate}

We consider that the effect of crop density on carabid activity density was caused by within-crop microclimate. The importance of microclimatic factors for the variation of carabid activity density has already been recognised. The activity density of carabid beetles is influenced by temperature and humidity conditions prevailing at the ground surface, and the opportunity for thermoregulation by exposure to sunshine (Honěk, 1988). The microclimate is determined by the density of the crop canopy. The sparse stand mitigates temperature fluctuations, provides

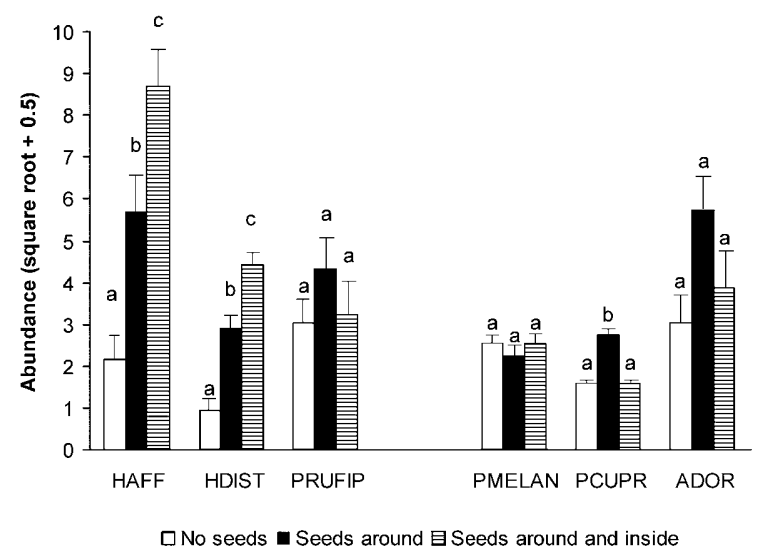

Fig. 4. The effect on carabid activity density of scattering rape seeds around, and around and inside traps compared to the control with no seeds outside or inside the trap (square root + 0.5 abundance). Bars with the same letters do not differ significantly in ANOVA tests. HAFF - H. affinis, HDIST - H. distinguendus, PRUFIP - P. rufipes, PMELAN - P. melanarius, PCUPR - P. cupreus, ADOR - A. dorsalis. a favourable humidity greater than on bare ground and sunspots where thermoregulation is possible. Very dense crop stands have a cool and moist microclimate and no sunspots on soil surface below the canopy. On sunny days in June-July in central Europe, the differences in temperature of shaded and bare ground surfaces in wheat stands exceeded $15^{\circ} \mathrm{C}$ (Honěk, 1985).

In this study the species apparently preferred a specific microclimate and selected canopy shaded or open places. The thermoregulatory and/or hygroregulatory function of carabid preference was apparent from correspondent changes of the distribution of $P$. rufipes and $H$. distinguendus with rape density in 1995 . In parallel with changes from cool and humid to warmer and drier microclimates as the crop matured and became sparse, the species activities shifted from bare ground to the more open canopy (Fig. 2). In pea and rape the proportion of carabids on bare ground increased as crops became dense (Fig. 3). This trend was essentially the same in both crops, and thus apparently related to crop density rather than other crop specific factors. The absence of a significant trend in wheat may be a statistical artefact. The range of observed densities in this crop was narrow (Fig. 3) and decreased range of densities reduces the likelihood of detecting density dependence (Draper \& Smith, 1981). Moreover, stem elongation and leaf development which determine ground shading in winter wheat stands are completed in late May. Subsequent small variations in crop biomass are largely caused by ear development that has little effect on crop microclimate. The fact that species selected the alternatives closer to their preferences - sparse stand instead of bare ground but bare ground instead of dense stand - can be a crucial factor determining carabid spatial distribution.

The microclimate probably also influenced between crop differences (Table 4) but its contribution was probably small and could be demonstrated indirectly. The evidence is a smaller similarity of carabid communities in winter wheat and winter rape in 1997 when crop densities differed greatly compared to a greater similarity in 1995 and 1996 when crop densities were similar. Further, in 1995 and 1996, the similarity between winter wheat and winter rape communities was greater using data from bare ground traps than within crop traps. This is probably because microclimates of crop and weed free plots were identical while the microclimates inside the crop stands were different. However, trophic conditions were probably more important determinant for between-crop differences.

\section{Seeds and aphids}

The availability of seeds which encouraged the abundance of Amara species in winter rape appeared important (Fig. 1). A. ovata and A. similata are seed eaters (Jørgensen \& Toft, 1997) and were abundant even in other studies of insect communities of winter rape (Jarošík \& Hůrka, 1986). The test with rape seeds baited in winter wheat confirmed the granivory of $H$. affinis and H. distinguendus (Fig. 4). However, the third abundant species regarded as primarily granivorous, $P$. rufipes, 
behaved in a similar way as the two carnivorous species, $P$. cupreus and $A$. dorsalis. This may suggest a greater importance of animal prey for this species. Aphid presence was only loosely correlated with carabid density. Of species recognised as aphid predators, only $B$. lampros and $T$. quadristriatus were significantly more abundant in winter wheat where aphid populations were present than in winter rape with no aphids (Fig. 1).

ACKNOWLEDGEMENTS. We thank K. Hůrka and P. Saska for valuable comments, and L. Kreslová and V. Poláková for excellent technical assistance. The work was supported by grants no. 522/97/0271 and 521/99/1116 of the Grant Agency of the Czech Republic to A.H. and MŠMT grant no. J13/98113100004 to V.J.

\section{REFERENCES}

ADIs J. 1979: Problems of interpreting arthropod sampling with pitfall traps. Zool. Anz. 202: 177-184.

BAKER A.N. \& DunNing R.A. 1975: Some effects of soil type and crop density on the activity and abundance of the epigeic fauna, particularly Carabidae, in sugar-beet fields. J. Appl. Ecol. 12: 809-818.

BILDE T. \& TOFT S. 1997: Consumption by carabid beetles of three cereal aphid species relative to other prey types. Entomophaga 42: 21-32.

BRANDMAYR T.Z. 1990: Spermophagous (seed eating) ground beetles: First comparison of the diet and ecology of the Harpaline genera Harpalus and Ophonus (Col., Carabidae). In Stork N.E. (ed.): The Role of Ground Beetles in Ecological and Environmental Studies. Intercept, Andover, Hampshire, UK, pp. 307-316.

ChIverton P.A. 1988: Searching behaviour and cereal aphid consumption by Bembidion lampros and Pterostichus cupreus, in relation to temperature and prey density. Entomol. Exp. Appl. 47: 173-182.

Cox D.R. 1970: Analysis of Binary Data. Monographs on Statistics and Applied Probability. Chapman and Hall, London.

CraWley M.J. 1993: GLIM for Ecologists. Blackwell, London, $379 \mathrm{pp}$.

Den Boer P.J. 1977: Dispersal power and survival. Carabids in a cultivated countryside. Misc. Pap. Landbouwhogeschool Wageningen Neth. 14: $190 \mathrm{pp}$.

Draper N.R. \& Sмith H. 1981: Applied Regression Analysis. John Wiley, New York.

ERICSON D. 1979: Interpretation of pitfall catches of Pterostichus cupreus and Pt. melanarius (Coleoptera, Carabidae) in cereal fields. Pedobiologia 19: 320-328.

Francis B. Green M. \& Payne C. 1994: The GLIM System. Release 4 Manual. Clarendon Press, Oxford, 821pp.

HoNĚK A. 1985: Activity and predation of Coccinella septempunctata adults in the field (Col., Coccinellidae). Z. Angew. Entomol. 100: 399-409.

HonĚK A. 1988: The effect of crop density and microclimate on pitfall trap catches of Carabidae, Staphylinidae (Coleoptera), and Lycosidae (Araneae) in cereal fields. Pedobiologia 32: 233-242.

HoNĚK A. 1991: Factors determining the peak abundance of Metopolophium dirhodum (Homoptera, Aphididae) on cereals. Bull. Entomol. Res. 81: 57-64.

HoNĚK A. 1997: The effect of plant cover and weather on the activity density of ground surface arthropods in a fallow field. Biol. Agric. Hortic. 15: 203-210.

HoNĚK A. \& MARTINKOVÁ Z. 1999: Host-plant mediated influences on population development of Sitobion avenae (Sternorrhyncha: Aphididae). Eur. J. Entomol. 96: 135-141.
HonĚk A. \& Pulpán J. 1983: The flight of Carabidae (Coleoptera) to light trap. Věst. Čs. Společ. Zool. 47: 13-26.

JAROŠ́́K V. \& HỨRKa K. 1986: Die Coleopterenfauna des Rapsfeldes. Věst. Čs. Společ. Zool. 50: 192-212.

JONES M.G. 1979: The abundance and reproductive activity of common Carabidae in a winter wheat crop. Ecol. Entomol. 4: $41-43$.

JøRGENSEN H.B. \& ToFT S. 1997: Role of granivory and insectivory in the life cycle of the carabid beetle Amara similata. Ecol. Entomol. 22: 7-15.

KokTA C. 1988: Beziehungen zwischen der Verunkrautung und phytophagen Laufkäfern der Gattung Amara. Mitt. Biol. BundAnst Ld-u. Forstw. 247: 139-145.

Krebs C.J. 1989: Ecological Methodology. Harper and Row, New York, 654pp.

Kromp B. 1990: Carabid beetles (Coleoptera, Carabidae) as bioindicators in biological and conventional farming in Austrian potato fields. Biol. Fert. Soils 9: 182-187.

Löver G.L. \& SUNDERLAND K.D. 1996: Ecology and behavior of ground beetles (Coleoptera: Carabidae). Annu. Rev. Entomol. 41: $231-256$.

LuFF M.L. 1987: Biology of polyphagous ground beetles in agriculture. Agric. Zool. Rev. 2: 237-278.

McCullagh P. \& Nelder J.A. 1989: Generalized Linear Models. 2nd ed. Chapman and Hall, London.

NovÁK B. 1967: Bindung der Imagines von manchen Feldcarabidenarten an die Lebensbedingungen in einem Gerstebestand (Coleoptera, Carabidae). Acta Univ. Palack. Olomouc. Fac. Rer. Nat. 25: 77-94 (in Czech).

PetrušKa F. 1971: The influence of the agricultural plants on the development of the populations of Carabidae living in the fields. Acta Univ. Palack. Olomouc. Fac. Rer. Nat. 34: 151-191.

SCHELLER H.V. 1984: The role of ground beetles (Carabidae) as predators on early populations of cereal aphids in spring barley. Z. Angew. Entomol. 97: 451-463.

SkUHRavÝ V. 1959: Die Nahrung der Feldcarabiden. Acta Soc. Entomol. Čechoslov. 56: 1-18.

SkuHravý V., Louda J. \& SÝKora J. 1971: Zur Verteilung der Laufkäfer in Feldmonokulturen. Beitr. Entomol. 21: 539-546.

SOKAL R. \& RoHLF F.J. 1981: Biometry. Freeman, San Francisco, 859 pp.

SopP P. \& WRATTEN S.D. 1986: Rates of consumption of cereal aphids by some polyphagous predators in the laboratory. Entomol. Exp. Appl. 41: 69-73.

Š́aldon E. 1982: Rastliná výroba [Crop Production]. Príroda, Bratislava, $628 \mathrm{pp}$, (in Slovak).

SunderLand K.D. \& Vickermann G.P. 1980: Aphid feeding by some polyphagous predators in relation to aphid density in cereal fields. J. Appl. Ecol. 17: 389-396.

Thiele H.U. 1977: Carabid Beetles in Their Environments. Springer, Berlin, $369 \mathrm{pp}$.

VAN DIJK T.S. 1987: The long-term effects on the carabid fauna of nutrient impoverishment of a previously arable field. Acta Phytopath. Entomol. Hung. 22: 103-118.

Varis A.L., Holopainen J.K. \& Koponen M. 1984: Abundance and seasonal occurrence of adult Carabidae (Coleoptera) in cabbage, sugar beet and timothy fields in southern Finland. $Z$. Angew. Entomol. 98: 62-73.

Walcin H. 1985: Spatial and temporal distribution of some abundant carabid beetles (Coleoptera: Carabidae) in cereal fields and adjacent habitats. Pedobiologia 28: 19-34.

Winder L., Hirst D.J., Carter N., Wratten S.D. \& Sopp P.I. 1994: Estimating predation of the grain aphid Sitobion avenae by polyphagous predators. J. Appl. Ecol. 31: 1-12. 
Zhavoronkova T.N. 1969: Certain structural peculiarities of the Carabidae (Coleoptera) in relation to their feeding habits. Entomol. Rev. 48: 462-471.

Received January 6, 2000; accepted June 2, 2000

ApPendx. Carabid species identified during the study.

A. meridianus (L.); Agonum muelleri (Herbst); Amara aenea (DeGeer); A.apricaria (Paykull); A. aulica (Panzer); A. bifrons (Gyllenhal); A. consularis (Duftschmid); A. equestris (Duftschmid); A. familiaris (Duftschmid); A. littorea Thomson; A. lunicollis Schioedte; A. majuscula Chaudoir; A. montivaga Sturm; A. nitida Sturm; A. ovata (F.); A. plebeja (Gyllenhal); $A$. similata (Gyllenhal); A. tibialis (Paykull); Anchomenus dorsalis (Pontoppidan); Anisodactylus binotatus (F.); A. signatus (Panzer); Asaphidion flavipes (L.); Badister lacertosus Sturm;
Bembidion lampros (Herbst); B. obtusum Audient-Serville; $B$. properans (Stephens); B. quadrimaculatum (L.); B. explodens Duftschmid; Calathus ambiguus (Paykull); C. fuscipes (Goeze); C. melanocephalus (L.); Carabus cancellatus L.; C. granulatus L.; Clivina fossor (L.); Harpalus affinis (Schrank); H. anxius (Duftschmid); $H$. atratus Latreille; $H$. distinguendus (Duftschmid); H. rubripes (Duftschmid); H. rufipalpis Sturm; H. signaticornis (Duftschmid); H. tardus (Panzer); Leistus ferrugineus (L.); Loricera pilicornis (F.); Microlestes minutulus (Goeze); Notiophilus aquaticus (L.); N. pusillus Waterhouse; Ophonus azureus (F.); O. rufibarbis (F.); Paratachys bistriatus (Duftschmid); Poecilus cupreus (L.); Pseudoophonus griseus (Panzer); P. rufipes (DeGeer); Pterostichus melanarius (Illiger); P. oblongopunctatus (F.); Stomis pumicatus (Panzer); Synuchus vivalis (Illiger); Trechus quadristriatus (Schrank) 